\title{
Article
}

\section{Inclusion as a Value in Participation: Children's Councils in Spain}

\author{
Javier Morentin-Encina ${ }^{1}$, Elena Noguera Pigem ${ }^{2}$, and María Barba Núñez ${ }^{3, *}$ \\ ${ }^{1}$ Department of Research Methods and Diagnosis in Education, Universidad Nacional de Educación a Distancia (UNED), \\ Spain \\ 2 Department of Theory and History of Education, University of Barcelona, Spain \\ ${ }^{3}$ Department of Pedagogy and Didactics, University of A Coruña, Spain \\ * Corresponding author (maria.barba@udc.es)
}

Submitted: 30 September 2021 | Accepted: 9 December 2021 | Published: 20 April 2022

\begin{abstract}
The two-way relationship between inclusion and participation makes municipal child participation organisations and experiences a key means of guaranteeing the inclusion in community life of children and adolescents, who are traditionally excluded from decision-making and the promotion of changes in the realities of their lives. One of the main objectives of municipal child participation organisations is to ensure that these spaces are inclusive. This means that they must promote equality of guarantees and conditions in the development of the right to participation from a perspective that addresses the different axes of inequality, not only in access to these spaces but also in the relational dynamics that take place in them. Based on a theoretical reflection on inclusion and participation, this article analyses the data from a questionnaire applied to 279 people (191 technical figures and 88 elected authorities) from 179 municipalities in Spain, which seeks to describe the state of child and adolescent participation in municipalities that are part of the International Association of Educating Cities, Child Friendly Cities, or both. A qualitative analysis is made of those issues related to the strategies used to promote inclusion within the Children's Councils, as well as in the initiatives promoted in the field of child participation. The results show agreement in considering Children's Councils to be inclusive bodies, but the means and procedures used do not always guarantee this inclusiveness.
\end{abstract}

\section{Keywords}

childhood; equal opportunities; human rights; inclusion; municipalities; participation

\section{Issue}

This article is part of the issue "Promoting Social Inclusive Experiences in Uncertain Times" edited by Ana Belén Cano-Hila (University of Barcelona).

(C) 2022 by the author(s); licensee Cogitatio (Lisbon, Portugal). This article is licensed under a Creative Commons Attribution 4.0 International License (CC BY).

\section{Introduction}

Social and community participation allows people to be and feel part of their community, get involved collectively, influence their realities, and establish a framework of relationships that will result in personal well-being and the improvement of the collective. Those working to promote quality of life, guarantee rights, and reduce social inequalities agree that participation is a key indicator of social inclusion (Contreras et al., 2015; EAPN Spain, 2020; Emaús, 2015; Verdugo et al., 2021). Access to community living spaces, active presence in them, involvement in common affairs, acceptance, and recog- nition by the group, taking on community roles, having a support network, and enjoying a sense of interdependence (Sharlock \& Verdugo, 2003) are defining features of participation and social inclusion. Recognising people's right to participation allows us to break with the power structure that places them in the position of those assisted and attended, of beneficiaries, recipients, singled out, and consequently excluded. It implies overcoming social, political, and educational dynamics of meddling and interfering in people's lives, denying their knowledge and taking away their autonomy, in favour of an action that respects the dignity of the person and the recognition of their capacities (Varela \& Morán, 2017). 
Child participation becomes a right and a clear means of social inclusion for a group that has traditionally been placed on the margins of community action and decisionmaking spaces. This exclusion is due to a conception of childhood as a "lack of," the "not yet" life stage (Casas, 2006), generating a double impact, that is, limiting access to opportunities for the development and emotional well-being of children and adolescents and hindering the advancement of our societies by failing to incorporate their viewpoints.

The United Nations Convention on the Rights of the Child (UN, 1989) indicates in article 12 the right of children to express their views freely in all matters affecting them, their opinions being considered following their age and maturity. Taking this into consideration implies going beyond giving children a voice; it implies guaranteeing that they are heard and that they have an impact on their realities. Lundy (2009), from the study on the obstacles that hinder the meaningful and effective application of this right, defends four principles in its realization: space, voice, audience, and influence. These elements should be approached from an individualized perspective and attentive to the scenarios of difficulty. General Comment No. 5 of the Convention (UN, 2003) indicates that the rights recognized in the Convention must be ensured for all, without discrimination or distinction, calling on states to actively identify children and groups of children who may see this right restricted and to adopt special measures to reduce or eliminate the conditions that lead to discrimination.

In the analysis of child participation or the exercise of citizenship, we cannot limit ourselves to a rights-based perspective. According to Lister (2007), it is necessary to consider participation in terms of "lived citizenship," a key element in children's development, in their sense of belonging to a community and in their recognition as members of that community. The author points out that "children can claim their status as members of the citizen community through their active participation in it; but in order to participate they must first be accepted as members of the citizen community" (Lister, 2007, p. 701). In this line, it is worth mentioning the promotion of mechanisms in recent years that allow this participation around projects such as the Children's City, Educating Cities, Child Friendly Cities (CFC-UNICEF), among others. These models vindicate the role of children as active citizens, enabling various institutionalised scenarios of involvement, such as municipal organisation for child and adolescent participation, participatory experiences of a consultative and projective nature led by the administration, or initiatives led by children and adolescents themselves (Novella et al., 2021). The Children's Councils, proposed by Tonucci (1997), become a key way to guarantee the inclusion of this group in community life. They function as municipal organisations that involve children and adolescents in the reflection and generation of proposals on aspects related to improving their realities of life.
As Trilla and Novella (2011) point out, they not only provide an educational opportunity for citizenship training and the development of associated competencies, but they are also understood as representative organisations, in which their members take on a representative role for those who elected them and, above all, for the children of the municipality as a whole. In general terms, they are usually made up of children and adolescents between 10 and 17 years of age, who meet periodically to deal with issues proposed by the Children's Council itself, by other children in the city, by social entities, or by the City Council's government team, and with autonomy to decide on the content of their work. A professional in charge of enhancing the educational dimension and establishing relations with the different municipal government agencies supports the meetings. Several studies address the concreteness of these participation models in their application in different territorial contexts (Alparone \& Rissotto, 2001; Golay \& Malatesta, 2014; Percy-Smith, 2010), counting on works that specifically put the gaze on the relationship between children's participation and the diversity of childhood. Wyness (2009) denounces that the methods for electing Children's Council members, based on standard electoral formulas, reinforce existing inequalities among youth groups and are less likely to incorporate the voices of disadvantaged and socially excluded children and adolescents. Children's Councils, as well as other initiatives, may see their function, both educational and representative, weakened if they are not projected as inclusive spaces, guaranteeing the equal possibility of participation of all groups, and integrating diverse children with their different sensitivities and needs.

Therefore, it is not enough to provide avenues for children's participation in community dynamics; we must also ensure that these spaces are inclusive. Recognising children's participation as a right implies assuming the responsibility of guaranteeing it for all people under equal conditions. It is necessary to go beyond formal recognition in favour of effective guarantee, which implies articulating the necessary means and training to make use of those means (Sen, 2000). It involves training for horizontal, dialogic, and egalitarian communication, for dialogic and consensual decision-making, for dealing with the mechanisms of privilege and oppression in these relational dynamics and confronting them, as well as enabling the resources that allow architectural, linguistic, economic, or cultural diversity barriers, among others, to be addressed. Inclusion implies transforming the systems and spaces of education and participation so that all people-without restrictions, limitations, or euphemisms as Echeita (2017) would say-have equal opportunities for their development and for influencing their realities. If we do not adopt the inclusion approach, we run two risks: (a) generating spaces that are tremendously homogeneous and poor in diversity, unrealistic to the extent that, according to Aguado et al. (2018), diversity is assumed as normality, and (b) that the most vulnerable 
children and adolescents, due to factors such as socioeconomic level, functional diversity, origin, ethnicity, age, gender, sexual diversity, territory, or unique living conditions, will be left out of these spaces, reducing their educational opportunities and increasing social inequality. An intersectionality approach (Crenshaw, 1989) is required to enable us to analyse and act sensitively on the different axes of privilege and oppression and how these are realised in social dynamics.

In the first instance, inclusion refers to ensuring access to participation opportunities for the whole population. Physical barriers and the absence of adaptation measures in the case of people with disabilities or economic barriers when actions involve a cost (even indirectly) are some of the factors that hinder simple access to these spaces. Considering the territorial variable, for example, we find that children in vulnerable urban contexts show relatively low participation due to cultural elements and a lack of resources and spaces to exercise this right (Cano et al., 2019; Quane \& Rankin, 2006). In rural contexts, the dispersion of the population makes it difficult for many children to participate, as well as the lack of resources, and they suffer from the digital divide due to the lack of a guaranteed rural broadband service, which has been particularly noticeable in the current times of pandemic (EAPN Spain, 2021).

However, we must pay attention to dynamics broader than access to Children's Councils, i.e., those dynamics of interaction, exchange, and decision-making. A first step in this direction has been that of representativeness, ensuring that those groups that are less represented in decision-making spaces have access to them. In this case, Children's Councils are made up of diverse children in terms of gender, social context, functional diversity, and other factors. Even so, the question of representation is insufficient; the challenge is to achieve high-quality participation for all children and adolescents, to democratise the educational space by guaranteeing the involvement of all people in decision-making (Aguado et al., 2018). We refer to equal guarantees and conditions in the development of the right to participate.

Romero et al. (2021) propose an analysis of child participation from three approaches: the capabilities, feminist, and intercultural approaches, which complement the extended rights-based approach. These approaches, which are not exclusive, make it possible to highlight the social, cultural, and institutional dynamics and barriers that limit children's participation, reflecting the power structures present in all societies. These structures translate into social dynamics that are reproduced, more explicitly or more subtly, in the spaces of relationships, interaction and social participation. The distribution of spaces, forms of organisation, the taking of the floor, the recognition of people, their speeches and contributions, etc., are all elements impregnated by logics of power, which come into play when promoting inclusive spaces.

In this sense, the attitude and training of the professionals who accompany these processes are key. We are talking about inclusion training in a general sense and, more specifically, in specific areas such as working with people with functional diversity, the implementation of the gender approach, and the intercultural approach as a critical communicative practice (Melero, 2018). However, just as it is a matter of training, it is also a matter of social awareness.

The position regarding diversity and inclusiveness of the people in the community and the professionals who accompany the process is decisive. For example, while it is true that the social participation of young people with disabilities is primarily affected by gaps in access and accessibility (Ferreira \& Oliver, 2019), the study by Ali et al. (2008) shows how, even when formal mechanisms are established to promote inclusion, people with intellectual disabilities often do not participate because of rejection and stigmatisation. This dynamic can be extended to any human group that suffers from a social ignorance that leads to rejection, contempt, or intolerant behaviours.

In this regard, it is interesting to highlight the initiatives promoted within the framework of municipal organisations for child participation that deal precisely with issues related to social progress towards more inclusive cities and contexts, which celebrate difference and recognise it as the richness of a territory, noting how children tend to participate from a perspective that promotes care for people.

Echeita (2017) indicates three major challenges for inclusive education in schools, applicable to municipal organisations for child participation: (a) welcoming all people in their diversity, respecting "the right to be and to share the common spaces where citizenship is built" (Echeita, 2017, p. 18); (b) that all children feel recognised and build meaningful social relationships within the group, in dynamics of care, as opposed to the construction of an identity based on lack and differentiation; and (c) to articulate sufficient strategies, forms of organisation, types of activities that allow the learning possibilities and contributions of all people to be enhanced without leaving anyone or anything out.

The challenge is not easy. Our societies are exclusionary and, if we disregard this one aspect, we will tend to reproduce exclusionary social spaces. A conscious effort needs to be made, in terms of process, to move towards other models. It is, therefore, worth exploring the approaches and strategies that are being activated in the municipalities' work to ensure that both the municipal organisation for child and adolescent participation and specific participation initiatives are inclusive spaces that guarantee that all children are part of, feel part of, and are recognised as active agents.

\section{Methodology}

This article draws on the research project Childhood and Participation: Diagnosis and Proposals for an Active and Inclusive Citizenship in the Community, Institutions 
and Governance (RTI2018-098821-B-I00), the purpose of which is to analyse the state of child participation in the municipalities that are part of the International Association of Educating Cities (IAEC) and the CFC-UNICEF.

To obtain information, a self-administered questionnaire study (Díaz de Rada, 2012, 2021) with exploratory and diagnostic value was carried out. There were 279 participants (191 technical figures [TFs] and 88 elected authorities [EAs]) from 179 municipalities belonging to the IAEC networks (24.2\%), the CFC-UNICEF (35.8\%), and other national networks in Spain related to child participation (12\%). Figure 1 shows the regions in which the questionnaires were conducted.

Two questionnaires were implemented: one for the TFs and one for the EAs. The research team designed both questionnaires in coordination with the CFC-UNICEF and the IAEC, and these were subsequently validated (Sabariego et al., 2021). Sampling was a two-stage cluster with the primary sampling units selected by accessibility (municipalities) and the final units by non-random routes and accessibility (TFs and EAs). For this article, TFs data has been used. TFs work in different municipal areas such as education (30\%), social services $(23 \%)$, children (12\%), youth $(11 \%)$, participation $(8 \%)$, culture $(5 \%)$, sustainability $(2 \%)$, or "other" (9\%). The persons referred to as EAs occupy political governance positions in the different town councils of the municipalities participating in the study.

The questionnaire addressed to TFs consisted of five sections, the third of which ("an exploration of initiatives or practices of child and adolescent participation in decision-making in the municipality that promote the exercise of active and inclusive citizenship, as well as their perceived impacts") has been selected for this study. The questions selected for this article read as follows:

1. Are Children's Councils inclusive institutions (because of social class, gender, ethnicity, age, sexual orientation, and functional diversity, among others) that cater to the diversity of children and adolescents in the municipality? If yes, briefly indicate how this inclusion is guaranteed.

2. Are the specific practices of participation an experience of inclusive participation (by social class, gender, ethnicity, age, sexual orientation, and functional diversity, among others) that caters to the diversity of children and adolescents in the municipality? If yes, briefly indicate how this inclusion is guaranteed.

Questions were open-ended, and while some participants answered, others did not; others gave answers that were not entirely coherent with what was being asked. Finally, the total number of people included in this study was 113 , with 140 responses.

The procedure used to make contact was to send an e-mail to the TFs by way of an invitation. After this, they were informed about confidentiality and informed consent following the Organic Law on Data Protection (Organic Law 3/2018 of 5 December). The questionnaires were collected between March and September 2020 and the research report (Novella \& Sabariego, 2020) was finalised at the end of October 2020.

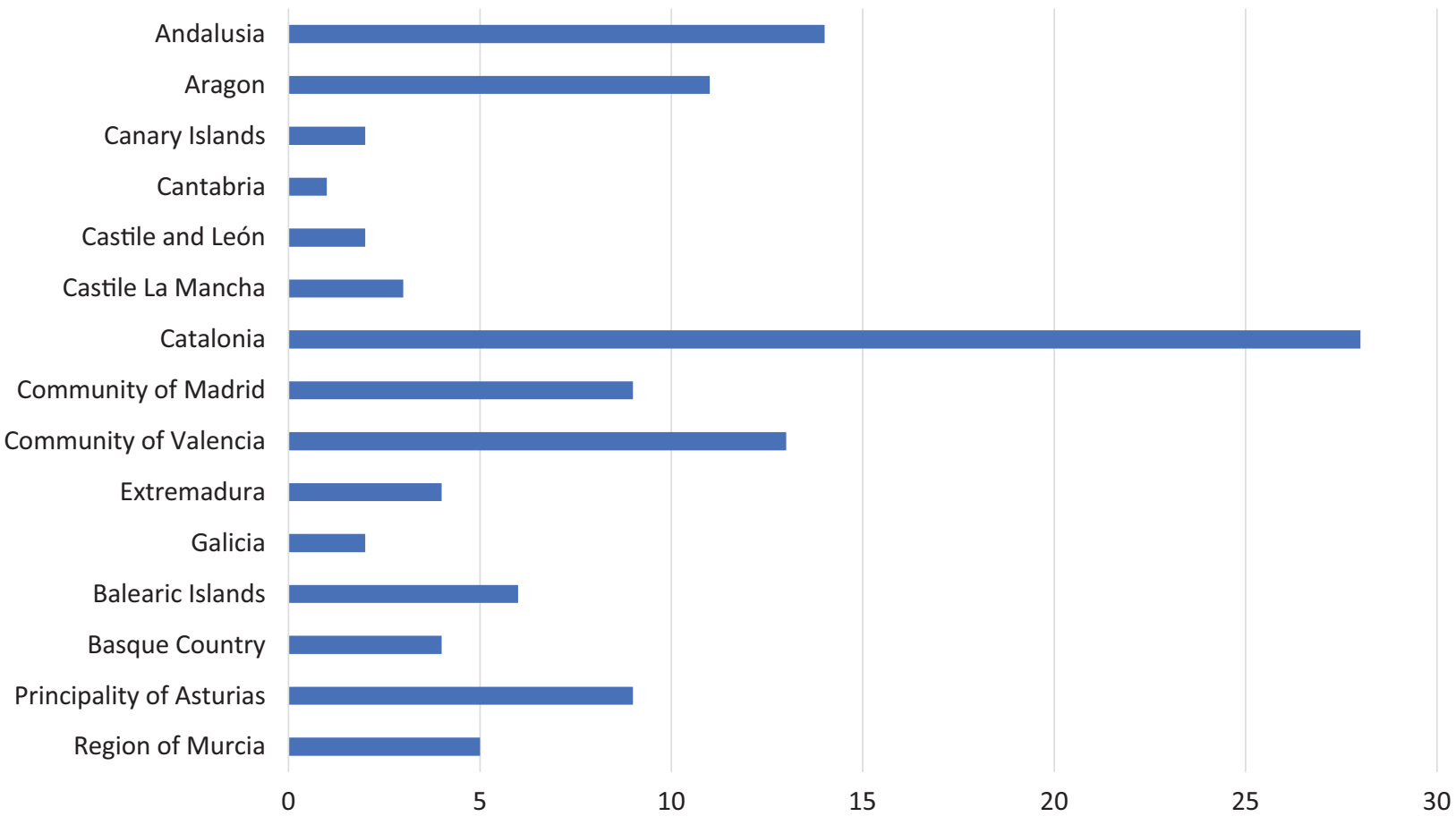

Figure 1. Number of questionaries collected by regions involved. 
For the analysis of the open-ended questions, a content analysis has been carried out in a mixed categorisation process (the Atlas.tiv.8 programme was used): First there was categorisation through the previously established questions; then, new categories were incorporated through an inductive process. These categories made it possible to relate the responses to this article's objective and to obtain the results shown in Figure 2 .

For the inductive creation of categories, an exploratory study was first carried out using a word cloud to guide us in creating the categories. After this first study, the creation of emerging categories began, resulting in the categories shown in Table 1.

This was followed by an analysis of the cooccurrences between the categories of the research questions (pre-established categories) together with the inductive (emergent) categories, as shown in Table 2.

Next, to analyse the most significant data from the research, a categorical network was generated, taking as a criterion a minimum of 10 codifications per category, resulting in the following network (Figure 3).

As can be seen in Figure 2, the categories with the highest number of citations were the ones represented, and "inclusion openness" and "diversity/deficit" were the most significant for the research.

\section{Results}

The analysis of the comments made by the TFs yields the following results.

First, the few answers to the question "how is inclusion in participation experiences ensured?" compared to the research question "how is inclusion in participation organisations ensured?" should be highlighted. From the answers obtained, it can be seen that the way to ensure this inclusion in the experiences is by opening the call for participation through the formal education system (pri- mary or secondary schools). The first number indicates the assigned informant number. The second digit is the appointment number created for that respondent:

6:7 The project is aimed at all schools in the municipality.

22:2 The entire school population of the seven schools participates.

23:1 The source of origin is the educational centres, being all the schools in the municipality.

24:1 All adolescents from the city's public secondary schools participate.

In addition, it is also determined that this inclusion is guaranteed by the participation of people from different areas, backgrounds, or groups:

\section{5:5 Special education centres participate.}

39:2 For this purpose, we have regular contact with social services and with entities that support children with disabilities, adapting the activities and methodology to their profiles.

43:2 Specific centres for functional diversity also participate.

57:6 The participants are boys and girls with educational needs and from vulnerable social backgrounds.

99:2 Participants from different origins, including North Africans, Africans, Latin Americans, among others. Participants belonging to LGBTIQ+ groups. Participants with functional diversity.

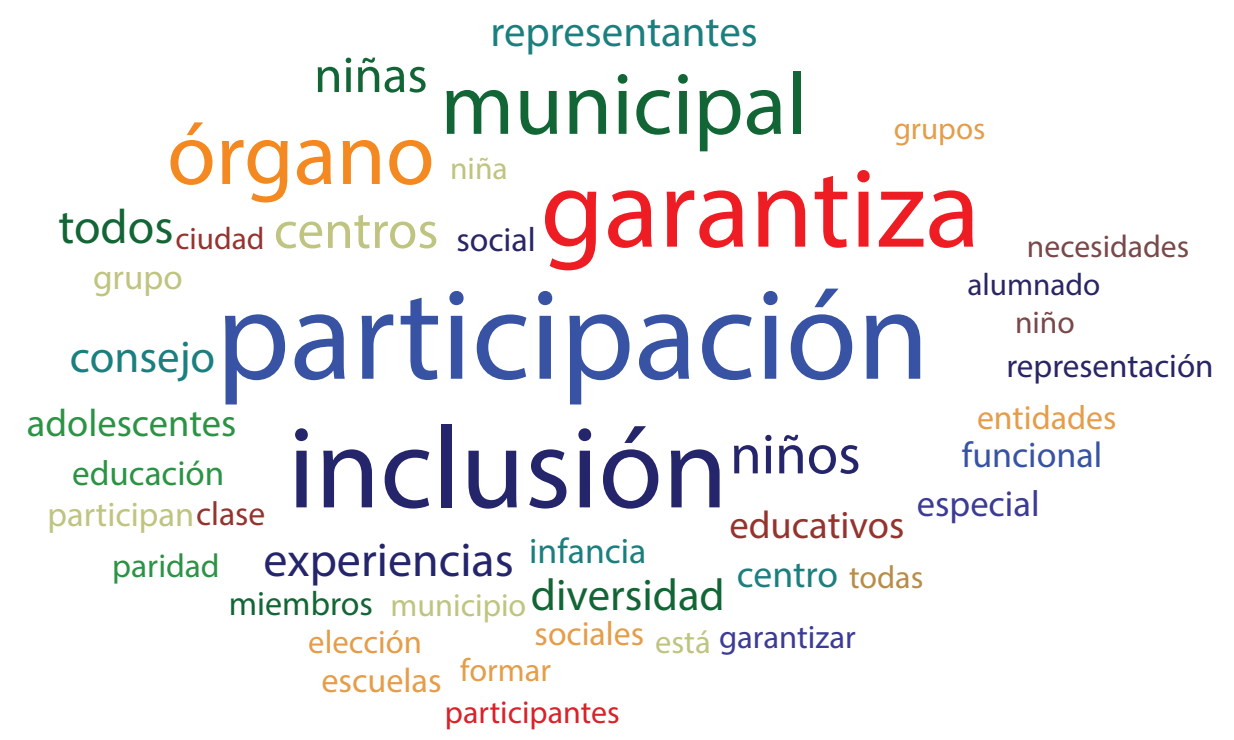

Figure 2. Word cloud. 
Table 1. Resulting categories.

\begin{tabular}{|c|c|c|}
\hline Codes & Explanation & Number of quotes \\
\hline Ensure inclusion in municipal body & Research question. & 102 \\
\hline DIVERSITY/DISABILITY & $\begin{array}{l}\text { Comments related to the conception of the term diversity, } \\
\text { whether understood as a person with a disability, } \\
\text { immigrant, social class, etc. }\end{array}$ & 58 \\
\hline INCLUSION OPENNESS & $\begin{array}{l}\text { Comments related to the profile of the people targeted for } \\
\text { inclusion. }\end{array}$ & 50 \\
\hline GENDER EQUALITY & $\begin{array}{l}\text { Comments related to gender equality, parity, the ratio of } \\
\text { female to male, etc. }\end{array}$ & 37 \\
\hline Ensure inclusion in experiences & Research question. & 36 \\
\hline ELECTION & Comments related to the procedure for electing members. & 28 \\
\hline INFORMATION & $\begin{array}{l}\text { Comments related to the dissemination of information to } \\
\text { raise awareness of programmes, organisations, etc. }\end{array}$ & 21 \\
\hline REPRESENTATIVES & $\begin{array}{l}\text { Comments related to those people who participate in } \\
\text { inclusion. }\end{array}$ & 20 \\
\hline PARTICIPATION & Comments related to how participation is applied. & 14 \\
\hline PROGRAMMING & $\begin{array}{l}\text { Comments related to the inclusion that is generated by a } \\
\text { programme's objectives or planning. }\end{array}$ & 9 \\
\hline RESOURCES & $\begin{array}{l}\text { Comments related to the provision of resources to meet } \\
\text { basic needs and generate inclusion. }\end{array}$ & 7 \\
\hline STRATEGIES AND INITIATIVES & $\begin{array}{l}\text { Comments related to those specific strategies or initiatives } \\
\text { that are carried out to generate inclusion. }\end{array}$ & 5 \\
\hline
\end{tabular}

Notes: Codes are ordered according to the number of citations obtained.

On the other hand, about ensuring inclusion in the municipal body, the TFs highlight, as they did for inclusion in the experiences, openness to the participation of different groups, offering training before the development of participation in the organisation, or providing resources for those people who need them:

14:3 Children who want to participate sign up voluntarily after a series of workshops that the educator carries out in all the educational centres of the municipality.
29:1 Open to any child in 4th or 5th year of primary school or 1st and 2nd year of secondary school, without excluding anyone for any reason, and providing the necessary resources that they may need.

89:1 Meetings are held in schools to promote inclusion. 22:1 In the absence of diverse representation in the results obtained in the elections, the psychopedagogical office will propose children to form part of the Council.

Table 2. Table of co-occurrences.

\begin{tabular}{lcr}
\hline & Ensure inclusion in municipal organisation & Ensuring inclusion in experiences \\
\hline DIVERSITY/DEFICIT & 44 & 14 \\
INCLUSION OPENNESS & 34 & 16 \\
V GENDER EQUALITY & 32 & 5 \\
ELECTION & 28 & 0 \\
INFORMATION & 19 & 2 \\
REPRESENTATIVES & 17 & 3 \\
PARTICIPATION & 9 & 5 \\
PROGRAMMING & 8 & 1 \\
RESOURCES & 4 & 3 \\
STRATEGIES AND INITIATIVES & 3 & 2 \\
\hline
\end{tabular}




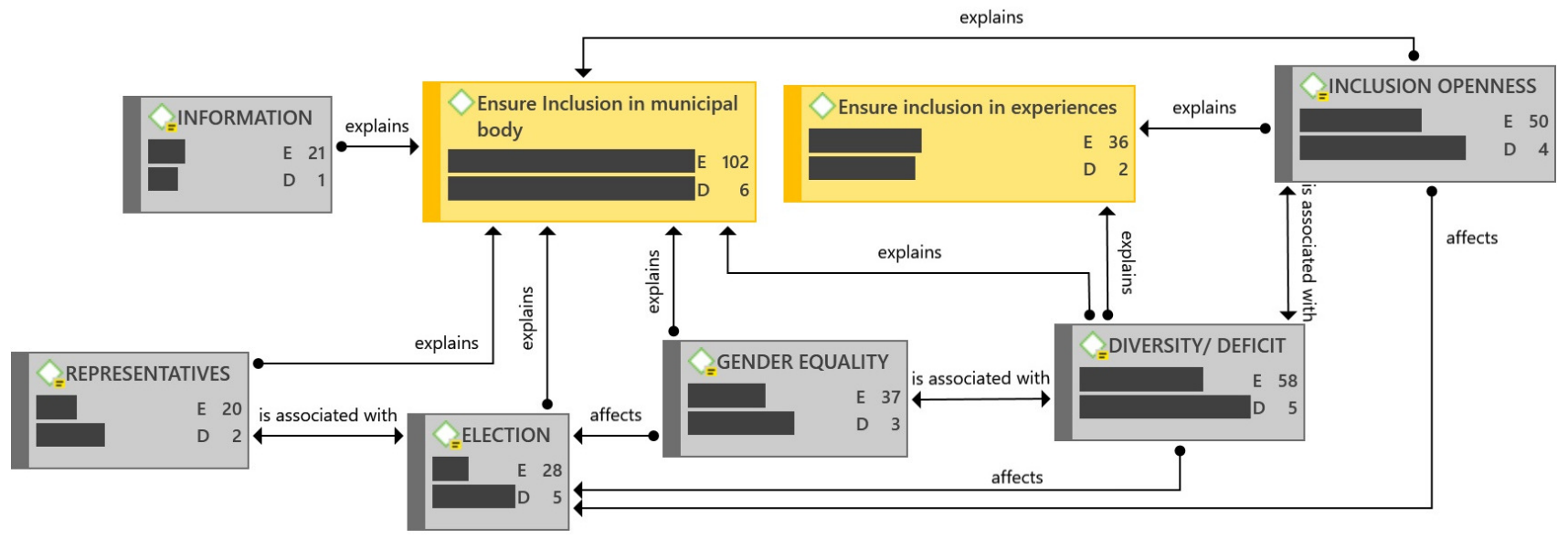

Figure 3. Categorial network (image generated by Atlas.ti 9).

52:1 Places are reserved for children with functional diversity and at risk of social exclusion.

Another means of inclusion highlighted by the TFs is that which refers to gender equality. Through the guidelines and indications given to the different educational centres, as well as the regulations governing the election of children and adolescents, they seek a parity of representation that ensures the representation of both genders. The schools are responsible for guaranteeing this equality and, on some occasions, they carry out positive discrimination to achieve it:

26:1 Gender, social class, and diversity are considered when setting up participation groups. Schools are responsible for ensuring this participation.

50:1 Representatives who attend the children's municipal plenary session must be selected based on gender parity criteria.

$55: 2$ In indications before the election of the pupils who participate, gender parity is suggested.

65:2 The only requirement to guarantee this is that there must be at least one girl among the representatives of each centre.

102:3 At the gender level, it is indicated in the municipal regulations that each centre must be genderequitable.

It also stresses the critical role of representatives' democratic election of the various participation organisations. Schools are responsible for calling these elections, and it is the pupils themselves who democratically elect their representatives. Some of them have guidelines provided by the TFs, which help make this electoral process more dynamic. Others promote positive discrimination within the election system to ensure the inclusion of all students, sometimes after the elections and sometimes carried out by educational professionals. As a measure of inclusiveness, in some cases, several representatives are elected by the school educators, and in other cases, these elections are carried out by drawing lots among the participating candidates:

9:1 The election of members is carried out democratically with an election process that educators drive in coordination with schools and local associations that work with children and adolescents.

20:4 Positive discrimination has an impact on the selection process in order to have a diverse profile of adolescents.

22:1 In the absence of a diverse representation in the results obtained in the elections, the psychopedagogical office will propose children be part of the Council.

61:1 The selection of participants with clear criteria of non-discrimination by their peers and part of the members selected by the educators, so that no one is left out.

76:4 The election of the representatives will be carried out by drawing lots among the candidates who decide to apply to be part of the Council in the different educational centres of the locality.

Finally, another measure to ensure inclusion in the children's participation organisation highlighted by the TFs is the dissemination of information. Thanks to this, they motivate and encourage the different educational centres, explaining what the child participation organisation consists of and inviting them to collaborate, thus promoting the commitment necessary for adequate participation:

6:6 Inclusion is ensured by paying special attention to and disseminating information in those schools 
where the most vulnerable groups are represented in order to make the integration of diversity possible.

17:1 The aim is to ensure that information on the formulas and channels for participation reach all children in the municipality, adapting to the needs of each child.

53:4 Work is carried out in schools explaining what the Council is and its functions, encouraging them to become candidates.

77:2 The first thing that was done was to encourage and invite them.

82:2 Information is provided to all citizens and anyone who wants to can participate.

\section{Discussion and Conclusions}

This article has sought to delve deeper into the inclusion of children and adolescents in participation to propose strategies that favour it not only as a policy approach but also in practice so that it can be implemented. The motivation is to promote participation and social change towards more meaningful equity effectively. We start from the inclusion of children and adolescents in municipal organisations, but we want to ensure that these children and adolescents are representatives of all children and adolescents and that they participate in inclusive experiences.

The total number of respondents included in this study was 113, with 140 responses, out of 191 questionnaires. This selection was made because the remaining questionnaires did not refer to participatory bodies or initiatives promoted in the municipality that dealt with inclusion, or the responses did not address what was asked. This lack of response is also relevant, given that it seems that they have not reflected on or are not activating specific strategies around this subject. Based on the obtained results, we consider that the omission of answers by technicians regarding the inclusion element in the experiences might be due to a lack of knowledge of what is specifically carried out in these experiences.

In the theoretical section, we talked about three spheres for ensuring inclusion and it is interesting to explore to what extent they are addressed: equity guarantee, equity in the forms of participation, and the themes on which the participation is based.

According to García (2019), any citizen should have the possibility to participate and exercise that right, and in the case that they do not get involved, it should be by choice and not because they do not have the opportunity or the information to do so. Many of the responses on inclusion in participation experiences and organisations refer to guaranteeing access; however, it is interesting to reflect on how they care about access.
The responses range from very limited discourses, which indicate that inclusion means allowing everyone to participate, without excluding anyone, to others who understand it as guaranteeing access from different spheres, backgrounds, or collectives, usually through institutional linkages. They cite linkages with specific functional diversity and special education institutions, support entities for children with disabilities, social services, institutions, and groups from different ethnic backgrounds and LGBTIQ+ groups. On the other hand, they do not mention adaptation measures in the case of people with disabilities, financial aid when the actions involve a cost or strategies to deal with territorial dispersion, among other aspects of inequality in access to participation.

As previously discussed, in the analysis of child participation or the exercise of citizenship, we cannot remain in the rights-based perspective. We have already referred to studies on participation models in different territorial contexts (Alparone \& Rissotto, 2001; Golay \& Malatesta, 2014; Percy-Smith, 2010), which draw a link between child participation and diversity. Wyness (2009) denounces how the election process for Children's Council members, based on standard electoral formulas, reinforces existing inequalities among youth groups and is less likely to incorporate the voices of disadvantaged and socially excluded childhoods.

For this reason, we highlight the importance of disseminating information to ensure inclusion in the organisations for children's participation. We must motivate and encourage the different educational centres to explain what child participation organisations consist of and encourage pupils to become candidates. Furthermore, we must work to ensure that schools do not reproduce segregationist patterns, selecting students with better academic performance or better communication skills. Participation must be understood as a right for everyone and as a learning opportunity, especially for those with greater difficulties. The objective is that the information on participation formulas and channels reach all children in the municipality, adapting to their individual needs. For this to happen, we must go beyond the schools, generating linkages with institutions that work with those children who tend to be left out, as the TFs shared in the questionnaires.

The questionnaire also allowed us to explore the responses that refer to the second level of inclusion, the strategies put in place in participatory spaces to ensure equal guarantees and conditions in developing the right to participate. The responses focus on representativeness, the activation of positive discrimination mechanisms, and parity and representation quotas, which allow diversity within the organisations but do not include specific strategies for moving from representativeness to real inclusion in the dynamics of participation.

As we said in the theoretical introduction, Council's members must assume a representative role of the municipality's children as a whole and incorporate diverse childhoods, with their different sensitivities and 
needs. Politically, they must assume the responsibility of guaranteeing the inclusion of all people, under equal conditions, who have equal opportunities for their development and for having an impact on their realities of life. This must be explicitly stated in institutional documents, in the Councils' rules and regulations.

From the analysed data, the different participation organisations representatives' democratic election critical role stands out. The responsibility for calling these elections lies with the municipalities or schools concerned, and it is the pupils themselves who democratically elect their representatives. Some of them have guidelines provided by the TFs that help make this electoral process more dynamic. Others promote positive discrimination within the election system to ensure the inclusion of all pupils, sometimes after the elections and carried out by educational professionals. Sometimes, as a measure of inclusion and to ensure fairness, some of the representatives are selected by the institutions themselves (schools and local associations working with children and adolescents). These elections are carried out on other occasions by drawing lots from the candidates who presented themselves. Sometimes the psycho-pedagogical office can propose children and adolescents to form part of the council, facilitating a diverse representation in the results obtained in the elections; places can be reserved for children and adolescents with functional diversity and at risk of social exclusion.

Another form of inclusion highlighted by the TFs is that which refers to gender equality. Through the guidelines and indications given to the different educational centres, as well as the regulations governing the election of children and adolescents with criteria of gender parity and equity, the aim is to achieve parity representation that ensures the representation of both genders. The centres themselves are responsible for guaranteeing this equality, and on some occasions, they carry out positive discrimination in order to achieve it.

Positive discrimination has an impact on the selection process to have diverse profiles of adolescents. There should be a selection of participants with clear non-discrimination criteria. Moreover, a number of participants could be selected by the school itself so that no one is left out.

Nevertheless, we must be aware that, beyond representation, there are power structures reproduced in the spaces for participation that we must address. Ensuring this aspect may be a question of both sensitivity and professional training. It is interesting to promote meeting spaces to reflect on what inclusion in a broad sense implies, as well as training in strategies to promote it. Besides, according to the work done in the research project Childhood and Participation: Diagnosis and Proposals for an Active and Inclusive Citizenship in the Community, Institutions and Governance, if we strengthen the coexistence of different scenarios, we will be bringing participation closer to the diversity of children and adolescents in the municipality, allowing them to develop participatory action from their scenario of affinity and comfort (Novella et al., 2021). Therefore, diversifying the spaces for participation can be another effective strategy.

In this last section of the article, we point out some limitations and proposals for continuity.

Concerning the sample and data collection, there was a limitation in conducting the questionnaire derived from the pandemic situation, and as the questions were open-ended, there were participants who did answer, others who did not, and others whose answers did not comply with what was asked. Undoubtedly, the pandemic (including confinement) exacerbated difficulties in access for TFs and different children and adolescents.

On the other hand, the results need to consider other contributions. The study we have carried out gathers the perceptions of the municipal technicians involved in the dynamization of child and adolescent participation on access to the Councils and inclusiveness in participation experiences. As a continuation of the research, a future line of work is proposed to deepen the impact analysis from other complementary perspectives (gathering data from children and adolescents themselves). Impact assessment requires a multidimensional vision and opens up new lines of research and action, such as longitudinal studies that follow up children throughout their participation trajectory or evaluation for empowerment, which focuses on the assessment of impact in terms of personal and social development (Cano et al., 2021).

We have described that the third sphere for ensuring inclusion is that of participation themes. However, the questionnaire did not allow us to analyse this particular dimension as this was a closed-ended question, and the categories did not directly relate to social inclusion issues. We consider that it would be interesting to explore this aspect at a later stage. We hope that in other phases of the research we will obtain more information on these issues using other instruments such as interviews and other qualitative techniques currently being implemented.

As future lines of research, we also consider that it would be interesting to explore institutional documents in order to analyse the specific measures that are articulated to guarantee inclusion.

Another consideration is the incorporation of a participatory methodology including young people so that they contribute to or guide the process and share the role of researchers, taking into account the concept of "ethical symmetry" proposed by Christensen and Prout (2002) to find a balance between the right to participation and the ethical dimension (Alfageme et al., 2003; Orgambídez et al., 2020).

As we have seen, the approach does not guarantee the result. There is political will, and there are policies of access to organisations as spaces for participation, but the relational dynamics within them need to 
be improved. There are tokenistic inclusive practices in the processes of participation, and these have little or no transformative power in society because the means and procedures used do not guarantee it, and we must improve them to enhance inclusion.

\section{Acknowledgments}

Our thanks to the technical and political staff of the municipalities that have participated in the research and to researchers from the four universities (University of Barcelona, UNED, University of Seville, and University of A Coruña) that collaborate in the R\&D project Childhood and Participation: Diagnosis and Proposals for an Active and Inclusive Citizenship in the Community, Institutions and Governance (RTI2018-098821-B-I00). This project is funded by the Ministry of Science and Innovation, the European Regional Development Fund, and the State Research Agency. This article was published thanks to the collaboration of our research group with the project KGR-Kids Got Rights (REC-AG-2020), the European Commission DG for Justice and Consumers of the Rights, Equality and Citizenship Programme (REC), and the support from the University of Barcelona for open access publishing.

\section{Conflict of Interests}

The authors declare no conflict of interests.

\section{References}

Aguado, T., Melero, H. S., \& Gil, I. (2018). Espacios y prácticas de participación ciudadana. Propuestas educativas desde una mirada intercultural [Spaces and practices of citizen participation. Educational proposals from an intercultural perspective]. RELIEVE, 24(2). http://doi.org/10.7203/relieve.24.2.13194

Alfageme, E., Martínez, M., \& Cantos, V. (2003). De la participación al protagonismo infantil: Propuestas para la acción [From child participation to child ownership: Proposals for action]. Plataforma de Organizaciones de Infancia.

Ali, A., Strydom, A., Hassiotis, A., Williams, R., \& King, M. (2008). A measure of perceived stigma in people with intellectual disability. The British Journal of Psychiatry, 193, 410-415. http://doi.org/10.1192/ bjp.bp.107.045823

Alparone, F. R., \& Rissotto, A. (2001). Children's citizenship and participation models: Participation in planning urban spaces and children's councils. Journal of Community \& Applied Social Psychology, 11(6), 421-434. https://doi.org/10.1002/casp.642

Cano, A., Pose, H., \& Gil, I. (2021). Impactos de las experiencias municipales de participación infantil y adolescente según los técnicos y técnicas locales [Impacts of municipal experiences of child and adolescent participation according to local technicians].
Revista Interuniversitaria, 38, 77-88. https://doi.org/ 10.7179/PSRI_2021.38.05

Cano, A. B., Sabariego, M., \& Folgueiras, P. (2019). La participación comunitaria de los jóvenes en contextos urbanos vulnerables: Aportaciones desde un diagnóstico colaborativo en el área metropolitana de Barcelona (España) [Community participation of young people in vulnerable urban contexts: Contributions from a collaborative diagnosis in the metropolitan area of Barcelona (Spain)]. OBETS: Revista de Ciencias Sociales, 14(2), 313-342. http://doi.org/ 10.14198/OBETS2019.14.2.02

Casas, F. (2006). Infancia y representaciones sociales [Childhood and social representations]. Política $y$ Sociedad, 43(1), 27-42. https://revistas.ucm.es/ index.php/POSO/article/view/POSO0606130027A

Christensen, P., \& Prout, A. (2002). Working with ethical symmetry in social research with children. Childhood, 9(4), 477-497. http://doi.org/10.1177/ 0907568202009004007

Contreras, J. M., Celis, R. Y., Martínez, J., Gutiérrez, A. A., \& Ortiz, R. K. (2015). Influencia de la participación social en el proceso de rehabilitación basada en comunidad, en las personas con discapacidad del municipio de Pamplona-Norte de Santander [Influence of social participation in the process of community-based rehabilitation in people with disabilities in the municipality of Pamplona, Santander North]. Revista Chilena de Terapia Ocupacional, 15(1), 85-96. http://doi.org/10.5354/07195346.2015.37133

Crenshaw, W. (1989). Demarginalizing the intersection of race and sex: A Black feminist critique of antidiscrimination doctrine, feminist theory and antiracist politics. University of Chicago Legal Forum.

Díaz de Rada, V. (2012). Ventajas e inconvenientes de la encuesta por internet [Advantages and disadvantages of the online survey]. Papers: Revista de Sociología, 97(1), 193-223. http://dx.doi.org/10.5565/ rev/papers/v97n1.71

Díaz de Rada, V. (2021). Utilización conjunta de encuestas administradas y autoadministradas. ¿Proporcionan resultados similares? [Using administered and self-administered surveys together: Do they provide similar results?]. Revista Española de Sociología, 30(1). https://doi.org/10.22325/fes/res.2021.09

EAPN Spain. (2021). Foro de debate sobre participación política y ciudadana [Debate forum on political and citizen participation]. European Anti-Poverty Network Spain.

Echeita, G. (2017). Educación inclusiva. Sonrisas y lágrimas [Inclusive education. Smiles and tears]. Aula Abierta, 46, 17-24. https://doi.org/10.17811/rifie. 46.2017.17-24

Emaús. (Eds.). (2015). Modelo inclúe: La apuesta por una atención de calidad en el ámbito de la inclusión social [Inclúe model: A commitment to quality care in the field of social inclusion]. 
Ferreira, N. R., \& Oliver, F. C. (2019). Los jóvenes con discapacidad y sus caminos de participación social [Young people with disabilities and their pathways to social participation]. Última Década, 27(52), 80-106. https://doi.org/10.4067/S0718-223 62019000200080

García, N. (2019). Abriendo caminos: Los procesos de participación ciudadana promovidos a nivel institucional en el ámbito local, como escuela de profundización democrática [Breaking new ground: Citizen participation processes promoted at the institutional level at the local level, as a school of democratic deepening]. FORUM, 15, 11-35. https://doi.org/10.15446/ frdcp.n15.73368

Golay, D., \& Malatesta, D. (2014). From formal rights to "living rights": Potentialities and limits of Children's Councils in terms of children's recognition as social actors. Global Studies of Childhood, 4 (2), 89-100. https://doi.org/10.2304/gsch.2014.4.2.89

Lister, R. (2007). Why citizenship: Where, when and how children? Theoretical Inquiries in Law, 8(2), 693-718. https://doi.org/10.2202/1565-3404.1165

Lundy, L. (2009). Voice is not enough: Conceptualizing article 12 of the United Nations Convention on the Rights of the Child. British Educational Research Journal, 33(6), 927-942. https://doi.org/10.1080/ 01411920701657033

Melero, H. S. (2018). Espacios y prácticas de participación ciudadana: Análisis y propuestas educativas desde un enfoque intercultural [Spaces and practices of citizen participation: Analysis and educational proposals from an intercultural approach] [Doctoral thesis, Universidad Nacional de Educación a Distancia]. Repository e-spacy. http://e-spacio.uned.es/ fez/view/tesisuned:ED-Pg-Educac-Hsanchez7

Novella, A. M., Mateos, T., Crespo, F., \& López, A. (2021). Escenarios de participación de la infancia: Oportunidades para la coproducción en los municipios [Children's participation scenarios: Opportunities for co-production in municipalities]. Pedagogía Social: Revista Interuniversitaria, 38, 61-76. https://doi.org/ 10.7179/PSRI_2021.38.04

Novella, A. M., \& Sabariego, M. (Eds.). (2020). Infancia y participación: Por una ciudadanía activa e inclusiva. Informe de resultados [Childhood and participation: For an active and inclusive citizenship. Results report]. University of Barcelona. https://doi.org/ 10.6084/m9.figshare.13296335.v2

Percy-Smith, B. (2010). Councils, consultations and community: Rethinking the spaces for children and young people's participation. Children's Geographies, 8(2), 107-122. https://doi.org/10.1080/1473 3281003691368

Quane, J., \& Rankin, B. (2006). Does it pay to participate? Neighborhood-based organizations and the social development of urban adolescents. Children and
Youth Services Review, 28(10), 1229-1250. https:// doi.org/10.1016/j.childyouth.2006.01.004

Orgambídez, A., Borrego, Y., \& Vázquez, O. (Eds.) (2020). Tendencias en intervención en investigación social [Trends in social research intervention]. In I. Rodríguez \& M. Martínez (Eds.), Infancia, investigación e intervención social: Horizontes metodológicos en diálogo [Childhood, research and social intervention: Methodological horizons in dialogue] (pp. 121-138). Dykinson.

Romero, C., Quirós, A., \& Buxarrais, M. R. (2021). Enfoques para promover la participación infantil y adolescente [Approaches to promoting child and adolescent participation]. Pedagogía Social: Revista Interuniversitaria, 38, 21-32. https://doi.org/ 10.7179/PSRI_2021.38.01

Sabariego, M., Izquierdo, A., Ruiz, A., \& Noguera, E. (2021). Validación por expertos del cuestionario "Infancia y Participación" [Expert validation of the questionnaire "Childhood and Participation"]. Pedagogía Social: Revista Interuniversitaria, 38, 33-46. https://doi.org/10.7179/PSRI_2021.02

Sen, A. (2000). Desarrollo y libertad [Development and freedom]. Editorial Planeta.

Sharlock, R., \& Verdugo, M. (2003). Manual para profesionales de la educación, salud y servicios sociales [Handbook for education, health and social services professionals]. Alianza Editorial.

Tonucci, F. (1997). La ciudad de los niños [The city of children]. Fundación GSR.

Trilla, J., \& Novella, A. M. (2011). Participación, democracia y formación para la ciudadanía: Los consejos de infancia [Participation, democracy and citizenship education: Local Children's Councils]. Revista de Educación, 356, 23-43. http://www.revistaeducacion. educacion.es/re2011/re2011_02.pdf

UN. (1989). Convention on the Rights of the Child.

UN. (2003). General measures of implementation of the Convention on the Rights of the Child.

Varela, L., \& Morán, C. (2017). A educación como instrumento de benestar nos servizos sociais [Education as an instrument of welfare in the social services sector]. Revista Galega de Educación, 67, 12-15.

Verdugo, M. A., Vicente, E., Guillén, V., Sánchez, S., Ibáñez, A., Fernández, R., Gómez, L. E., Coma, T., Bravo, M. A., \& Vived, E. (2021). Escala AUTODDIS: Evaluación de la autodeterminación de jóvenes y adultos con discapacidad intelectual [AUTODDDIS Scale: Assessment of self-determination of young people and adults with intellectual disabilities]. Instituto Universitario de Integración en la Comunidad.

Wyness, M. (2009). Children representing children: Participation and the problem of diversity in UK youth councils. Childhood, 16(4), 535-552. https://doi.org/ 10.1177/0907568209344274 


\section{About the Authors}

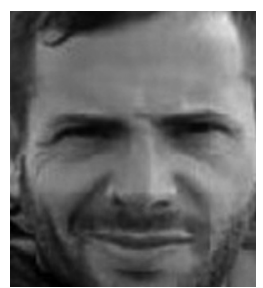

Javier Morentin-Encina is a researcher through a research staff development grant awarded by the Universidad Nacional de Educación a Distancia (UNED) and a teaching associate in the Department of Research Methods and Diagnosis in Education I. He is a graduate in social education with a major in care for people at risk of social exclusion and holds a master's degree in innovation and research in education. He earned his PhD in education sciences from UNED and is a member of the Intercultural Education Research Group. His lines of research are intercultural education, school dropout, and citizenship and participation.

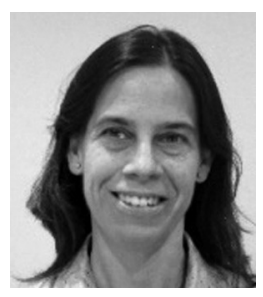

Elena Noguera Pigem is a professor in the Department of Theory and History of Education in the Faculty of Education at the University of Barcelona. She teaches education (bachelor's degree level) and digitally mediated learning environments (master's degree level). She is a member of the Research Group in Moral Education (GREM) and holds a PhD in educational sciences from the University of Barcelona. She coordinates the research of the European project Kids Got Rights.

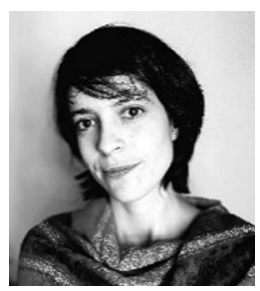

María Barba Núñez is a social educator and holds a PhD in educational sciences from the University of Santiago de Compostela. She currently works as a teacher and researcher in the Department of Pedagogy and Didactics at the University of A Coruña, linked to the ECIGAL research group. She has been researching for years on issues of social inclusion and community participation, especially with the prison population. She is currently president of the social inclusion association Aliad Ultreia. 